\title{
Failure Analysis of Column-Slab Connections with Stud Shear Reinforcement
}

\author{
Hong Guan* and Yew-Chaye Loo \\ School of Engineering, Griffith University Gold Coast Campus, PMB 50 Gold Coast Mail \\ Centre, Queensland 9726, Australia
}

\footnotetext{
${ }^{*}$ Corresponding author. Tel: +61-7-5552-8708; fax: +61-7-5552 8065.

E-mail address: H.Guan@griffith.edu.au (H. Guan).
} 
Abstract: The design of a flat plate structure is generally governed either by serviceability limits on deflection or punching shear strength of the column-slab connections. To increase the strength of a column-slab connection, a new type of shear reinforcement, referred to as shear stud, is gaining popularity in practice. In this paper, a nonlinear layered finite element method (LFEM) is used to investigate the effectiveness of the shear studs in increasing the punching shear strength of edge and corner column-slab connections. In total, nine large-scale reinforced concrete slabs of a flat plate floor in the vicinity of edge and corner columns, tested previously in the laboratory, are analysed. All the slabs contained stud shear reinforcement (SSR) except a control slab where no SSR was provided. The test variables were the column size and the stud spacing to slab thickness ratio. The punching shear strengths, load-deflection responses and crack patterns predicted by the LFEM are compared with the experimental results. The numerical investigation confirms the accuracy and effectiveness of the LFEM in predicting the strength of column-slab connections with SSR.

Key words: Column-slab connection; concrete flat plate; punching shear; stud shear reinforcement; finite element analysis. 


\section{Introduction}

The concrete flat plate system is a slab and column structure without drop panels and column capitals at the slab and column connections. From an aesthetic and economic point of view, the flat plate structure has an advantage over other slab systems due to the significant savings in construction costs and an aesthetically pleasing appearance especially from the slab soffit. In addition, the elimination of beams and girders reduces the overall floor depths of multistorey buildings thus creating additional floor space for a given building height. For these reasons, flat plates are widely used for multistorey structures such as office buildings and carparks in many countries.

In the design of concrete flat plates, the punching shear strength around the column-slab connections always poses a critical analysis problem. Punching shear failure would occur at a load well below the flexural capacity due to the concentration of shear forces and the unbalanced loading condition resulted from the concentration of both bending and twisting moments, which leads to unsymmetrical stress distribution around the column-slab connections. The local and brittle nature of the punching shear failure is in the form of column punching through the slab along a truncated cone caused by diagonal cracking around the column. Erroneous punching shear design has been shown to lead to catastrophic failure. An example of such catastrophe is the 1995 collapse of Korea's 6-year old Sampoong Department Store in Seoul under service condition, which killed some 500 people (Gardner et al. 2000). In view of the complexities of the basic three-dimensional behaviour of the column-slab connections and the uncertainty of the shear transfer mechanism, punching shear strength and failure analysis of concrete flat plates have become one of the challenging topics of intensive research in recent years by various concrete structure researchers worldwide.

The punching resistance of reinforced concrete flat plates can be increased by various means. The structural members such as column cross section can be enlarged and the portion of slab around the column can be thickened (i.e. drop panels and column capitals). From an aesthetic and economic point of view, such solutions are not feasible as larger columns reduce the available space and thicker slabs increase dead load and the subsequent construction cost for 
foundations. In terms of the material used, increasing the amount of flexural reinforcement (Alexander and Simmonds 1992) and the concrete compressive strength (Gardner 1990) have certain beneficial effect. However this approach is less effective in increasing ductility and is not practical in many cases. For slab-column connections, particularly in resisting horizontal forces caused by wind and earthquakes, the structural capacity can be enhanced by constructing spandrel beams along the edges of the slab (Falamaki and Loo 1992). Despite its efficiency in improving the structural performance, the existence of the spandrel beam further complicates the already complex punching shear behaviour of the slab-column connections. In view of this, the introduction of shear reinforcement has become the most economical solution, as it can be effective in reducing the chances of a brittle type of failure at slab-column connections.

The performance of many types of shear reinforcement including vertical and inclined stirrups, structural shear heads, bent-up bars, hooked bars and welded-wire fabric have been tested extensively in the last three decades (Broms 1990; Elgabry and Ghali 1990; Mortin and Ghali 1991; Chana 1991; Hammill and Ghali 1994; Lim and Rangan 1995; Ghali and Dilger 1998). It has been well accepted that an appropriate use of shear reinforcement improves both punching shear resistance and ductility. Such shear reinforcement is usually provided to achieve a ductile failure mode caused by yielding of flexural reinforcements at ultimate load. Stirrups have been frequently used in the 70's (Hawkins et al. 1975). However, the installation of stirrups has been found to be costly because it complicates the placement of the flexural reinforcement due to the relatively thin slabs. To meet the requirements of strength, ductility and economy, a research team (Seible et al. 1980) at the University of Calgary has developed three types of preassembled shear reinforcing units namely the I-segments, the headed shear studs and the welded wire fabric. The team has further developed a new type of shear reinforcement, in the form of a stud with an anchor head and a steel strip welded respectively to its top and bottom (Mokhtar et al. 1985). Tests of eight full-sized slab-column connections with shear studs revealed that such studs are easy to install, reduce congestion and they do not interfere with flexural reinforcement, and most importantly the anchorages at the top and bottom are sufficient to develop yielding in the shear studs before failure thereby creating a more ductile failure mode. The tests also confirmed that the use of shear studs increases the load carrying capacity, the punching shear strength and ductility of the flat concrete plates (Mokhtar et al. 1985). Due to the 
fact that the tests undertaken at the University of Calgary (Seible et al. 1980; Mokhtar et al. 1985; Ghali and Hammill 1992) were performed on a series of isolated slab-column connection assemblies, Lim and Rangan (1995) have recently tested nine reinforced concrete slabs of a flat plate floor in the vicinity of edge and corner columns with stud shear reinforcement (SSR). The benefits of using SSR in such concrete slabs have once again been validated.

Many major national codes of practice for concrete structures include recommendations for the analysis of the punching shear strength of concrete flat plates. However, no specific recommedations are available to cover flat plates reinforced by SSR. The Australian Standard AS3600-2001 (SAA 2001) does not preclude but makes no provision for the design of SSR. Where the slab contains any other types of shear reinforcement than closed ties, the punching shear strength is calculated based on equations for slabs with no shear reinforcements but with slight modification. Based on the initial development work on SSR carried out by Seible et al. (1980) at the University of Calgary, Dilger and Ghali (1981) suggested code provisions for the design of SSR for slabs. It has since been adopted for punching shear design by the North American codes including ACI318 code (ACI 1989) and Canadian Standard CSA-A23.3 (CSA 1994). The European codes such as BS8110 (BS 1997), Eurocode EC2 (EC2 1991) amd CEB-FIP Model Code-90 (CEB-FIP 1990) differ from North American codes in checking the punching shear critical section and steel rail arrangement. In addition, they specify a smaller shear-reinforced zone than North American codes (Ghali and Megally 2000). Both the North American and the European codes primarily cover the design provisions for interior column-slab connections with SSR, however no specific recommendations are available for edge column-slab connections with SSR, in particular, when the column is of rectangular shape (Lim and Rangan 1995).

Needless to say, laboratory tests are labour-intensive, time-consuming and costly. On the other hand, various empirical and code methods, based heavily on model test results, inevitably involve gross approximations which are not always reliable and, by nature, their scope of applications is limited. Non-linear finite element analysis, however, provides a method by which structures could be analysed to progressive failure. It is evident that non-linear analysis of concrete structures has become increasingly important and useful in recent years. For flat plates and slabs, the punching shear failure behaviour has been investigated extensively using special 
purpose finite element analysis packages where concrete and reinforcing bars are modelled by three-dimensional brick elements with embedded bar elements (Khwaounjoo et al. 1999a, 1999b; Staller 2000; Bhatt and Lim 2000; Ožbolt et al. 2000). An efficient and inexpensive layered finite element method has also been developed to model punching shear in flat plates, slabs and slab-column connections (Loo and Guan 1997; Guan and Loo 1997; Polak 1998), where shell elements are used encompassing concrete and smeared steel layers. However, little work has been done in the punching shear analysis of slab-column connections with shear reinforcement (Polak 1998; Khwaounjoo et al. 1999a, 1999b; Beutel et al. 2000).

In this study, a nonlinear layered finite element method (LFEM) (Loo and Guan 1997) is used to predict the load-carrying capacity and the punching shear strength of edge and corner column-slab connections with SSR. Seven edge and two corner column-slab connections tested by Lim and Rangan (1995) are investigated with such variables as the column size and the ratio of stud spacing to slab thickness. The punching shear strengths, the deflections and the crack patterns predicted by the LFEM are compared with the experimental results.

\section{Semi three-dimensional layered finite element approach}

\subsection{Finite element model}

For a rigorous cracking and punching shear failure analysis of reinforced concrete flat plates, a nonlinear layered finite element method (LFEM) has been developed by Guan and Loo (1997). Figure 1a illustrates the concept of the 8-node degenerate, quadratic, isoparametric shell element encompassing concrete and smeared steel layers. Five degrees of freedom are specified at each nodal point. They are the in-plane displacements, $u$ and $v$, transverse displacement $w$, and two independent bending rotations about the $x$ and $y$ axes, i.e. $\theta y$ and $\theta x$ respectively. The layered model makes use of the transverse shear deformations associated with the Mindlin hypothesis. In the layered approach, each element is subdivided into a chosen number of layers which are fully bonded together. The stress distributions of concrete and steel layers are illustrated in Fig. 1b. The concrete characteristics are specified individually for each layer over its thickness. On the other hand, each layer of the reinforcing bars (in-plane) is smeared across 
the element and given an equivalent thickness. The transverse reinforcement is modelled as a property of a concrete layer associated with the normal strain $\left(\varepsilon_{z}\right)$ in the transverse direction. In a nonlinear analysis, the material state at any Gauss point located at the mid-surface of a layer can be elastic, plastic or fractured according to the loading history. To account for the mechanical change of the materials throughout the incremental loading process, cracking and nonlinear material response are traced layer by layer.

By incorporating all the in-plane and out-of-plane stress components in the finite element formulation, the layered model is capable of simulating inclined cracks. As a result, the prediction of transverse punching shear failure of column-slab connections in flat slabs becomes possible without resorting to the use of expensive fully three-dimensional elements.

\subsection{Material model}

In the LFEM, the failure of reinforced concrete is considered to be a result of either tension cracking in concrete or plastic yielding which leads to the crushing of concrete. An elastic brittle fracture behaviour is assumed for concrete in tension. Cracked concrete is treated as an orthotropic material using a smeared crack representation and the tension cut-off depiction is ultilised. This is achieved using the maximum tensile stress criterion. In cracked concrete, the tensile and shear stresses acting on the crack plane are released and redistributed to surrounding elements. Under subsequent loading, concrete loses its tensile strength normal to the crack direction, but retains the tensile strength in the directions parallel to the crack plane. Due to the aggregate interlock and bond effects, both the reduced shear moduli and the tension stiffening effect are taken into consideration. The compressive behaviour of concrete is modelled using the strain-hardening plasticity approach. Also called the work-hardening theory of plasticity, it determines the boundaries of elastic and plastic regions of a stressed material. It also determines the progress of damage growth in the plastic zone of a material. When the compression type of failure transpires in concrete some strength and rigidity of the material is lost. Numerical modelling of either cracking or crushing of concrete involves the modification of material stiffness and the release of the appropriate stresses partially or completely in the fractured elements. 
The reinforcing steel is assumed to be elastic-plastic uniaxial material. The in-plane reinforcing bars at a given level in an element are modelled as a smeared steel layer of equivalent thickness. The out-of-plane reinforcement (shear stud) can be included by adding its contributions to the material matrix, which corresponds to the normal strain in the transverse direction.

The total material matrix containing the contributions of concrete and steel can be determined for each element and the stiffness matrix for the corresponding element can be evaluated. The global stiffness matrix is then assembled using the standard procedure. An incremental and iterative procedure is used to obtain the nonlinear solution due to both material and geometric nonliearities.

The LFEM is capable of solving three-dimensional problems of reinforced concrete slabs and flat plates and of analysing both flexural and shear cracking up to failure. In addition to the prediction of punching shear strength at slab-column connections, the method is also capable of determining the load-deflection response, the ultimate load capacity, the deformed shape and the crack patterns of the structures. It is considered far superior to the code methods and other existing empirical approaches including the "truss theory" (Lim and Rangan 1995) which are capable of predicting only the punching shear strength.

\section{Test slabs}

Tests on nine large-scale reinforced concrete slabs of a flat plate floor in the vicinity of edge and corner columns have been reported by Lim and Rangan (1995). The purpose of the tests was to study the effectiveness of stud shear reinforcement (SSR) in increasing punching shear strength of column-slab connections. In the experimental work, two parameters were investigated, viz the column size and the ratio of stud spacing to slab thickness. The test specimens were designated as Slab 1, the control specimen; Slabs 2, 3, 4, 5, 6A and 7, the edgecolumn connections; and Slabs 8 and 9, the corner-column connections. The overall dimensions and support conditions of the test slabs are shown in Figs. 2a and 2b, respectively, for the edge 
and corner column-slab connections. The slab thickness is $110 \mathrm{~mm}$. Slabs 1, 2, 3, 8 and 9 have square columns with dimensions of $250 \times 250 \mathrm{~mm}$, whereas Slabs 4 and 5 and Slabs $6 \mathrm{~A}$ and 7 have dimensions of $150 \times 600 \mathrm{~mm}$ and $150 \times 400 \mathrm{~mm}$, respectively. Also shown in Fig. 2 are the three locations of dial gauges for deflection measurement (i.e. Points D1, D2 and D3), as well as the positions of 24 (for the edge column-slab connections) and 16 (for the corner column-slab connections) point loads placed in a symmetric grid on the slab. These point loads were applied in the test to simulate a uniformly distributed vertical load. Each slab contains four layers of flexural reinforcing bars of $8 \mathrm{~mm}$ diameter. The percentages of steel provided in various regions of the test slabs represent those used in a flat plate prototype floor in the vicinity of a column (Rangan and Lim 1992). The column size $\left(c_{1} \times c_{2}\right)$, the concrete strength $\left(f_{c}^{\prime}\right)$, the yield strength of steel reinforcement $\left(f_{y}\right)$ and the stud spacing/slab thickness ratio $\left(s / h_{s}\right)$ for each slab are summarised in Table 1. Further details of the test specimens can be found elsewhere (Rangan and Lim 1992; Lim and Rangan 1994).

Slab 1 is a control specimen which has no SSR, whereas Slabs 2 to 9 contain SSR in the vicinity of the column. The arrangements of stud rails in the test slabs are illustrated in Figs. 3a and 3b, respectively, for the edge and corner column-slab connections. In all the slabs, two stud rails were located at each face of the column. In Slabs 2 to 7, six stud rails were used whereas four stud rails were used in Slabs 8 and 9. The dimensions of the stud and the position of the stud rail in the slab are shown in Fig. 4, where the SSR is composed of vertical bars with anchor heads, welded to a steel rail at the bottom. The $s / h_{s}$ ratios given in Table 1 indicate that the spacing of the studs is equal to one-half of the slab thickness in Slabs 2, 4, 6A and 8, and is equal to the slab thickness in Slabs 3, 5, 7 and 9.

\section{Numerical analysis of column-slab connections}

\subsection{Finite element simulation}

The main purpose of the numerical analysis is to verify the accuracy and reliability of the LFEM in predicting the punching shear strength, the collapse load, the load-deflection response up to failure, as well as the crack patterns of column-slab connections with and without SSR. To 
this end, a comparative study is carried out in the light of Lim and Rangan's test results (1992, 1994) from seven edge and two corner column-slab connections. Also included in the study are the Lim and Rangan's empirical approach based on the truss theory.

For the seven edge column-slab connections, only half of each of the slabs is analysed on account of symmetry whereas the entire slab is modelled for each of the two corner column-slab connections. The finite element mesh scheme used for each slab is also summarised in Table 1 and the graphical representations of the finite element mesh are shown in Figs. 5a and 5b, respectively, for the edge (Slabs 2 and 3) and corner (Slabs 8 and 9) column-slab connections. As can be seen in the figure, unequal-sized meshes are adopted to account for the non-uniformly spaced reinforcement as well as the locations of the dial gauges. In addition, refined meshes are used around the column region where punching failure would occur. In all the slab models, each element is subdivided into eight concrete layers of different thicknesses. The thinnest concrete layers are placed at the bottom and top of the element. The layer thickness gradually increases towards the element mid-surface. This is to provide a more account of the extensive cracking near the bottom and top surfaces. The top and bottom reinforcement meshes are represented by four (smeared) steel layers with equivalent thickness. The equivalent thicknesses of the stud rails and anchor heads are added to the top and bottom smeared steel layers at relevant locations (see Fig. 4). The out-of-plane shear studs are modelled by adding their contributions to the material matrix that corresponds to the normal strain $\left(\varepsilon_{z}\right)$ in the transverse direction. To better simulate the concentrated effect of the shear studs, the meshes at the stud locations are made relatively thin and the corresponding equivalent stud ratios are considered along each role of the studs.

The experimental support conditions are fully simulated in the analysis. The load is applied incrementally through the loading points as indicated in Fig. 2. Larger load increments are applied at the initial stages followed by gradually decreased increments up to the failure load.

\subsection{Punching shear strength and failure load}

A comparison of the values of the punching shear strength $V_{u}$ for all the slabs is summarised in Table 2 which includes the test results, the LFEM predictions and the calculated 
values due to the truss theory (Lim and Rangan 1995). The ratio of the experimental and predicted $V_{u}$ as well as that of the experimental and calculated $V_{u}$ are also included in the table. The comparison shows that the LFEM predicts closely the punching shear strengths of the edge column-slab connections but underestimates those of the corner column-slab connections. In general, however, both the predictions by the LFEM and the truss theory correlate well with the test results, having mean ratios of 0.98 and 1.02 respectively. The correlation coefficients for the LFEM and the truss theory are 0.99 and 0.97 respectively. Table 2 also reveals that the use of SSR is effective in increasing $V_{u}$ and, at either stud spacing. However, like the experimental findings, the column size $\left(c_{1} \times c_{2}\right)$ and the $s / h_{s}$ ratio do not seem to have significant influence on the punching shear strength.

The failure loads predicted by the LFEM agree remarkably well with the measured values, as evident in Table 3. The ratio of the experimental and predicted failure load varies between 0.92 and 1.07 for the nine slabs, with a mean ratio of 1.01 and a correlation coefficient of 0.94 . It can also be seen in the table that Slabs 2 to 9 carry significantly more loads than Slab 1 due to the presence of SSR. In addition, the numerical results indicate that Slabs 2 to 7 deflect more than Slab 1 (see Fig. 6) because they carry greater loads which would cause more extensive cracking. This is also in accordance with the experimental findings. Further, the column size does not seem to have significant effect on the failure load. However, the smaller the $s / h_{s}$ ratio, the greater the failure load, except for Slabs 4 and 5 for which the failure loads are almost identical.

\subsection{Load-deflection responses}

For the edge column-slab connections, the deflections at Points D1 and D2 (see Fig. 2a) are noted which correspond to the dial gauge locations in the test. The predicted and experimental load-deflection responses are compared in Fig. 6. Figure 6a is for the control slab (Slab 1). Figures $6 \mathrm{~b}$ and $6 \mathrm{c}$ are respectively for Slabs 2 and 3 that have the same square columns but differ in the $s / h_{s}$ ratios, and for Slabs 4 and 5 that have the same rectangular columns but also differ in the $s / h_{s}$ ratios. The LFEM, as evident in Fig. 6, is able to predict the actual load-deflection response reasonably well. For all the slabs, except Slab 1, the predicted ultimate deflections are 
smaller than the observed ones. This is not unlike other finite element analyses, which usually yield stiffer solutions due to the relatively coarse but economic mesh size adopted.

For the corner column-slab connections, the deflections at Points D1, D2 and D3 (see Fig. 2b) are examined. The response curves are presented in Fig. 7 for Slabs 8 and 9 that have the same column size but differ in the $s / h_{s}$ ratios. Again good correlations exist between the predicted and the test results.

\subsection{Crack patterns}

The comparisons of the predicted and observed crack patterns at both the bottom and top surfaces of Slabs 3 (symmetrical half) and 8 are shown in Figs. 8 and 9, respectively. Same as in the experiment (Lim and Rangan 1995), the LFEM predicts a punching shear failure with the formation of the characteristic punching cone. It is evident that extensive cracking has developed at failure at the mid-span of the bottom surface of the slab whereas $45^{\circ}$ cracks have occurred on the top surface of the slab near the column. It should be noted that a numerical analysis would normally show more cracks than the experimental observation (Loo and Guan 1997). This discrepancy can however be alleviated when a finer mesh is adopted. Taking this fact into account, the agreement between the predicted and observed crack patterns is considered satisfactory.

\section{Conclusions}

An analytical study is carried out on the punching shear strength of edge and corner column-slab connections with and without stud shear reinforcement (SSR). The investigation is based on a nonlinear layered finite element method (LFEM) developed previously by the authors. Seven edge and two corner column-slab connections tested in the laboratory are analysed. The connections differ in the column sizes $\left(c_{1} \times c_{2}\right)$ and the stud spacing/slab thickness ratios $\left(s / h_{s}\right)$. The punching shear strengths, the load-deflection responses and the crack patterns predicted by the LFEM are compared with the experimental results. The study confirms that 
- $\quad$ the use of SSR is effective in increasing the punching shear strength of both edge and corner column-slab connections;

- $\quad$ an increase in the amount of SSR generally increases the load carrying capacity of the slab;

- $\quad$ however, for the slabs tested, the column size $\left(c_{1} \times c_{2}\right)$ and the $s / h_{s}$ ratio do not seem to have significant influence on the punching shear strength.

The LFEM has shown to be able to predict with good accuracy the punching shear strengths, the load-deflection responses and the crack patterns of reinforced concrete flat plates with spandrel beams or torsion strips. The same is true in predicting the strength of edge and corner column-slab connections with and without SSR. The method satisfactorily and consistently performs for slabs with different column dimensions and different amount of stud shear reinforcements. In addition, the LFEM is capable of predicting the load-deflection responses, the collapse loads as well as the progressive crack patterns up to failure, which is superior to many existing commercial finite element analysis packages where cracking cannot be monitored.

Further verification of the analytical method outlined in this paper is being carried out based on the tests on slab-column connections reinforced by SSR, conducted at the University of Calgary (Mortin and Ghali 1991). In addition, a parametric study will be performed to investigate the punching shear strength of column-slab connections with SSR influenced by varying, in a range of practical interest, the concrete properties, the column sizes and the stud spacing/slab thickness ratios.

\section{Acknowledgments}

The authors would like to thank Mr Suphol Boonnoy, the former undergraduate student of Griffith's School of Engineering, for his assistance in preparing some of the input data for the numerical analysis. 


\section{References}

Alexander, S.D.B., and Simmonds, S.H. 1992. Tests of column-flat plate connections. ACI Structural Journal, 89(5): 495-502.

American Concrete Institute (ACI) 1989. Building code requirements for reinforced concrete (ACI 318-89) and commentary - ACI318R-89, Detroit, Michigan.

Beutel, R., Schmidt, M., and Landauer, A. 2000. 3D numerical punching analysis of shear reinforced flat slabs - variation of quantity and arrangement of stirrups. Proceedings of the International Workshop on Punching Shear Capacity of RC Slabs, Stockholm, Kungl Tekniska Hogskolan - Royal Technical University, pp. 181-189.

Bhatt, P., and Lim, B.T. 2000. Punching shear failure of flat slabs: a comparison between nonlinear finite element analysis predictions and experiments. Proceedings of the International Workshop on Punching Shear Capacity of RC Slabs, Stockholm, Kungl Tekniska Hogskolan - Royal Technical University, pp. 47-55.

British Standards Institution (BSI) 1997. BS8110: 1997, Part 1, Code of Practice for the Structural Use of Concrete, London.

Broms, C.E. 1990. Shear reinforcement for deflection ductility of flat plates. ACI Structural Journal, 87(6): 696-705.

Canadian Standards Association 1994. Design of concrete structures, Standard CSA-A23.3-94, Ontario, Canada.

CEB-FIP 1990. Model code for concrete structures (MC-90), Thomas Telford Ltd., London.

Chana, P.S. 1991. Punching shear in concrete slabs. The Structural Engineer, 69(15): 282-285.

Dilger, W.H., and Ghali, A. 1981. Shear reinforcement for concrete slabs. Proceedings, ASCE, 107(ST12): 2403-2420.

Elgabry, A., and Ghali, A. 1990. Design of stud-shear reinforcement for slabs. ACI Structural Journal, 87(3): 350-361.

European Committee for Standardisation 1991. Eurocode 2, Design of concrete structures, Part I: General rules and rules for buildings, ENV 1992-1-1, Brussels.

Falamaki, M., and Loo, Y.C. 1992. Punching shear tests of half-scale reinforced concrete flat plate models with spandrel beams. ACI Structural Journal, 89(3): 263-271. 
Gardner, N.J. 1990. Relationship of the punching shear capacity of reinforced concrete slabs with concrete strength. ACI Structural Journal, 87(1): 66-71.

Gardner, N.J., Huh, J., and Chung, L. 2000. What can we learn from the Sampoong department store collapse. Proceedings of the International Workshop on Punching Shear Capacity of RC Slabs, Stockholm, Kungl Tekniska Hogskolan - Royal Technical University, pp. 225232.

Ghali, A., and Dilger, W.H. 1998. Anchoring with double-head studs. Concrete International, 2124.

Ghali, A., and Hammill, N. 1992. Effectiveness of shear reinforcement in slabs. Concrete International, 60-65.

Ghali, A., and Megally, S. 2000. Stud shear reinforcement for punching: North American and European practices. Proceedings of the International Workshop on Punching Shear Capacity of RC Slabs, Stockholm, Kungl Tekniska Hogskolan - Royal Technical University, pp. 201209.

Guan, H., and Loo, Y.C. 1997. Layered finite element method in cracking and failure analysis of RC beams and beam-column-slab connections. Structural Engineering and Mechanics - An International Journal, 5(5): 645-662.

Hammill, N., and Ghali, A. 1994. Punching shear resistance of corner slab-column connections. ACI Structural Journal, 91(6): 697-707.

Hawkins, N.M., Mitchell, D., and Hanna, S.N. 1975. The effects of shear reinforcement on the reversed cyclic loading behaviour of flat plate structures. Canadian Journal of Civil Engineering, 2: 572-582.

Khwaounjoo, Y.R., Foster, S.J., and Gilbert, R.I. 1999a. Influence of boundary conditions on punching shear behaviour of flat plate-column connections. Proceedings of the $16^{\text {th }}$ Australasian Conference on the Mechanics of Structures and Materials, Sydney, Australia Balkema, pp. 145-150.

Khwaounjoo, Y.R., Foster, S.J., and Gilbert, R.I. 1999b. The influence of concrete material parameters on the FE modelling of punching shear in flat plate-column connections. Proceedings of the $16^{\text {th }}$ Australasian Conference on the Mechanics of Structures and Materials, Sydney, Australia - Balkema, pp. 151-156. 
Lim, F.K., and Rangan, B.V. 1994. Strength of concrete slabs with stud shear reinforcement in the vicinity of edge and corner columns. Research Report No.1/94, Curtin University of Technology, Perth, Australia.

Lim, F.K., and Rangan, B.V. 1995. Studies on concrete slabs with stud shear reinforcement in vicinity of edge and corner columns. ACI Structural Journal, 92(5): 515-25.

Loo, Y.C., and Guan, H. 1997. Cracking and punching shear failure analysis of RC flat plates. Journal of Structural Engineering, ASCE, 123(10): 1321-1330.

Mokhtar, A., Ghali, A., and Dilger, W.H. 1985. Stud shear reinforcement for flat concrete plates. ACI Journal, 82(5): 676-683.

Mortin, J.D., and Ghali, A. 1991. Connection of flat plates to edge columns. ACI Structural Journal, 88(2): 191-198.

Ožbolt, J., Vocke, H. and Eligehausen, R. 2000. Three-dimensional numerical analysis of punching failure. Proceedings of the International Workshop on Punching Shear Capacity of RC Slabs, Stockholm, Kungl Tekniska Hogskolan - Royal Technical University, pp. 65-74.

Polak, M.A. 1998. Modeling punching shear of reinforced concrete slabs using layered finite elements. ACI Structural Journal, 95(1): 71-80.

Rangan, B.V., and Lim, F.K. 1992. Tests on concrete slabs with stud shear reinforcement in the vicinity of edge columns. Research Report No.1/92, Curtin University of Technology, Perth, Australia.

Seible, F., Ghali, A. and Dilger, W.H. 1980. Preassembled shear reinforcing units for flat plates. ACI Journal, Proceedings, 77(1): 28-35.

Staller, M.A. 2000. Analytical studies and numerical analysis of punching shear failure in reinforced concrete slabs. Proceedings of the International Workshop on Punching Shear Capacity of RC Slabs, Stockholm, Kungl Tekniska Hogskolan - Royal Technical University, pp. 367-374.

Standards Association of Australia (SAA) 2001. AS3600-2001: Concrete structures, Sydney, Australia. 


\section{List of symbols}

$\begin{array}{ll}c_{1}, c_{2} & \text { column size } \\ h_{s} & \text { slab thickness } \\ f_{c}^{\prime} & \text { compressive strength of concrete } \\ f_{y} & \text { yield strength of steel } \\ s & \text { stud spacing } \\ u, v, w & \text { nodal displacements } \\ V_{u} & \text { punching shear strength of reinforced concrete flat plates } \\ \theta_{x}, \theta_{y} & \text { nodal rotations }\end{array}$


Table 1. Relevant data for test slabs.

\begin{tabular}{ccccccc}
\hline Slab No. & Column type & $\begin{array}{c}\text { Column size } \\
c_{1} \times c_{2}(\mathrm{~mm})\end{array}$ & $f_{c}^{\prime}(\mathrm{MPa})$ & $f_{y}(\mathrm{MPa})$ & $s^{\prime} h_{s}$ & $\begin{array}{c}\text { Mesh } \\
\text { scheme }\end{array}$ \\
\hline 1 & Edge & $250 \times 250$ & 25.0 & 516 & - & $12 \times 11$ \\
2 & Edge & $250 \times 250$ & 26.9 & 516 & 0.5 & $15 \times 13$ \\
3 & Edge & $250 \times 250$ & 27.5 & 516 & 1.0 & $15 \times 13$ \\
4 & Edge & $150 \times 600$ & 26.3 & 546 & 0.5 & $15 \times 12$ \\
5 & Edge & $150 \times 600$ & 27.7 & 546 & 1.0 & $15 \times 12$ \\
$6 \mathrm{~A}$ & Edge & $150 \times 400$ & 35.5 & 524 & 0.5 & $15 \times 13$ \\
7 & Edge & $150 \times 400$ & 27.7 & 515 & 1.0 & $15 \times 13$ \\
8 & Corner & $250 \times 250$ & 32.5 & 515 & 0.5 & $14 \times 13$ \\
9 & Corner & $250 \times 250$ & 33.3 & 515 & 1.0 & $14 \times 13$ \\
\hline
\end{tabular}


Table 2. Comparison of punching shear strength $V_{u}(\mathrm{kN})$.

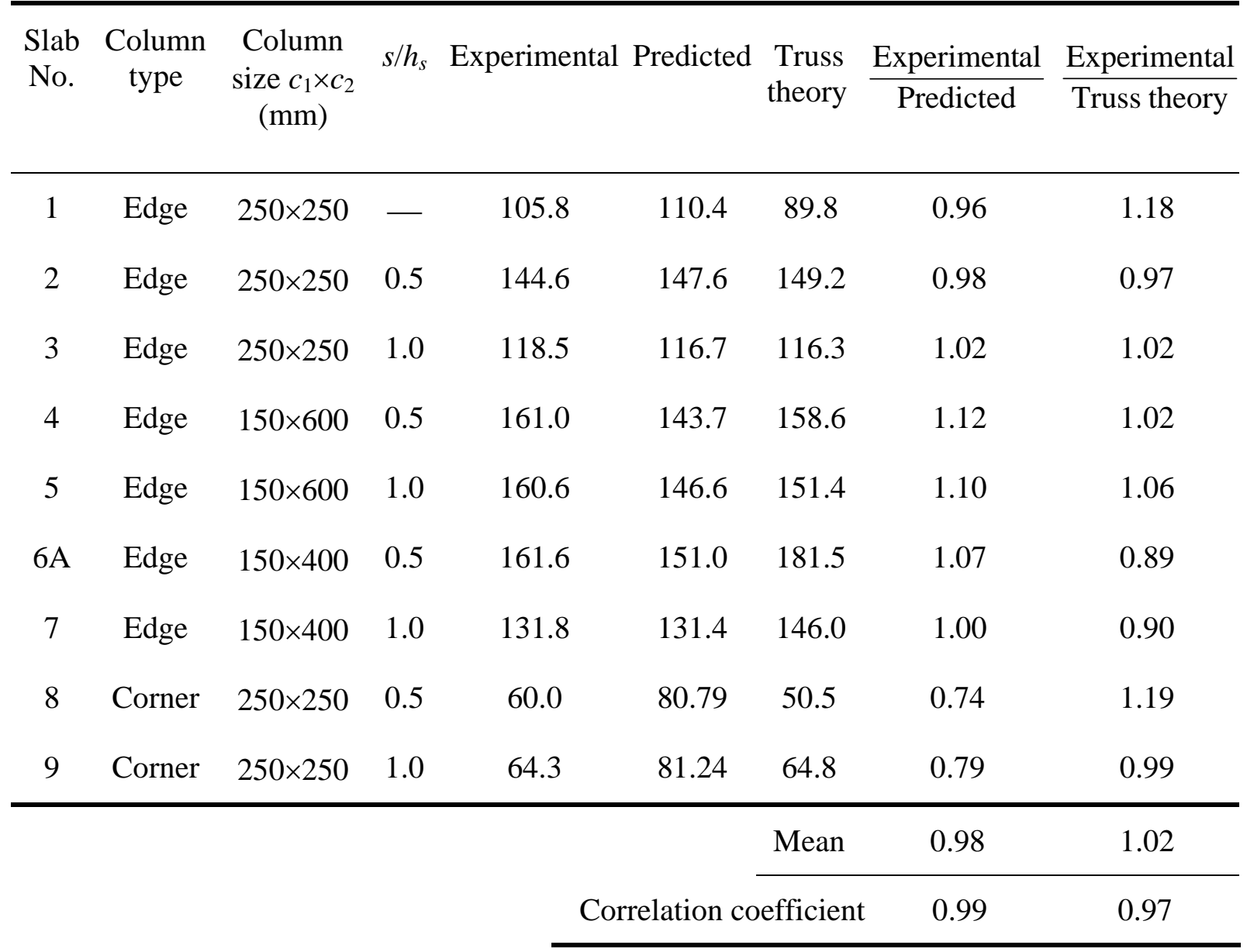


Table 3. Comparison of failure load $\left(\mathrm{kN} / \mathrm{m}^{2}\right)$.

\begin{tabular}{|c|c|c|c|c|c|c|}
\hline Slab No. & $\begin{array}{l}\text { Column } \\
\text { type }\end{array}$ & $\begin{array}{l}\text { Column size } \\
c_{1} \times c_{2}(\mathrm{~mm})\end{array}$ & $s / h_{s}$ & Experimental & Predicted & $\frac{\text { Experimental }}{\text { Predicted }}$ \\
\hline 1 & Edge & $250 \times 250$ & - & 21.92 & 23.87 & 0.92 \\
\hline 2 & Edge & $250 \times 250$ & 0.5 & 30.81 & 31.23 & 0.99 \\
\hline 3 & Edge & $250 \times 250$ & 1.0 & 25.76 & 25.66 & 1.00 \\
\hline 4 & Edge & $150 \times 600$ & 0.5 & 34.17 & 32.22 & 1.06 \\
\hline 5 & Edge & $150 \times 600$ & 1.0 & 35.27 & 33.02 & 1.07 \\
\hline $6 \mathrm{~A}$ & Edge & $150 \times 400$ & 0.5 & 35.74 & 35.40 & 1.01 \\
\hline 7 & Edge & $150 \times 400$ & 1.0 & 29.00 & 31.23 & 0.93 \\
\hline 8 & Corner & $250 \times 250$ & 0.5 & 27.74 & 27.45 & 1.01 \\
\hline \multirow[t]{3}{*}{9} & Corner & $250 \times 250$ & 1.0 & 27.66 & 25.88 & 1.07 \\
\hline & & & & & Mean & 1.01 \\
\hline & & & & \multicolumn{2}{|c|}{ Correlation coefficient } & 0.94 \\
\hline
\end{tabular}




\section{List of Figures}

Fig. 1. Layered finite element: (a) degenerate shell element with concrete and steel layers; (b) stresses in concrete and steel.

Fig. 2. $\quad$ Layout of test slabs: (a) Slabs 1 to 7; (b) Slabs 8 and 9.

Fig. 3. Arrangement of stud rails in slabs: (a) Slabs 2 to 7; (b) Slabs 8 and 9.

Fig. 4. Position of stud rail in slab.

Fig. 5. $\quad$ Finite element mesh: (a) Slabs 2 and 3; (b) Slabs 8 and 9.

Fig. 6. Load-deflection responses for edge column-slab connections: (a) Slab 1; (b) Slabs 2 and 3; (c) Slabs 4 and 5.

Fig. 7. Load-deflection responses for corner column-slab connections: (a) Slab 8; (b) Slab 9.

Fig. 8. Comparison of crack patterns for Slab 3 (symmetrical half): (a) predicted pattern for bottom layer; (b) observed pattern of bottom surface; (c) predicted pattern for top layer; (d) observed pattern of top surface.

Fig. 9. Comparison of crack patterns for Slab 8: (a) predicted pattern for bottom layer; (b) observed pattern of bottom surface; (c) predicted pattern for top layer; (d) observed pattern of top surface. 
(a)

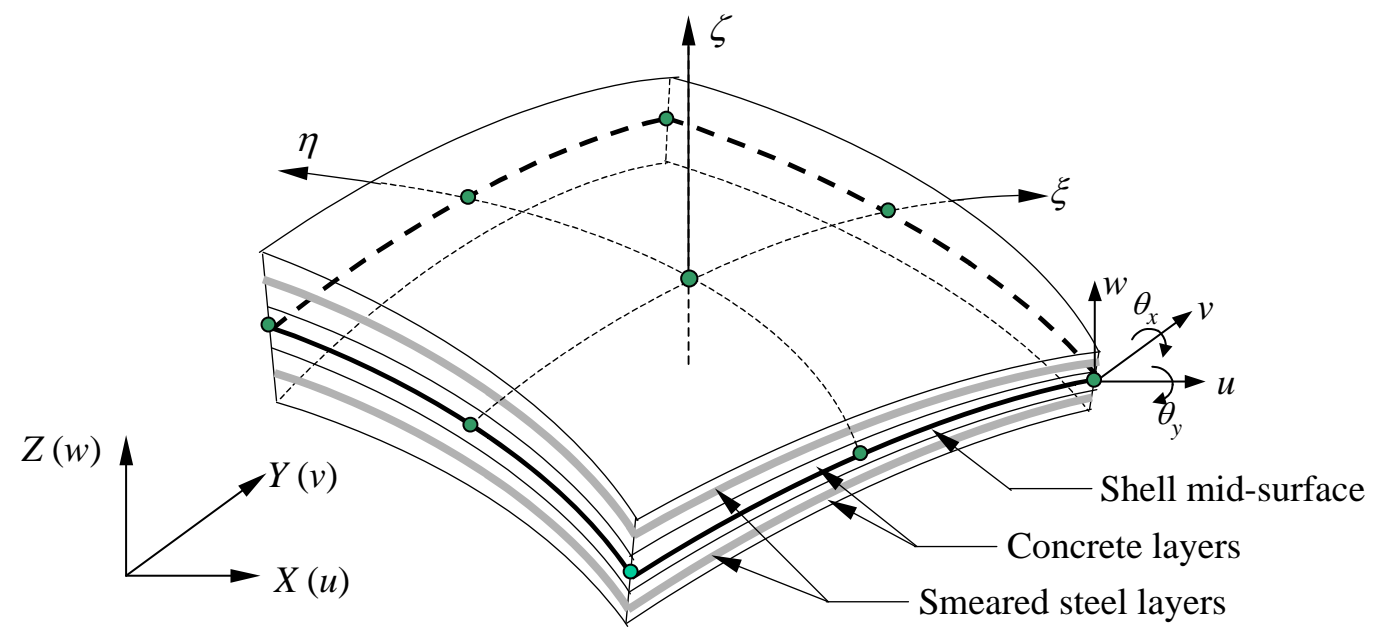


(b)

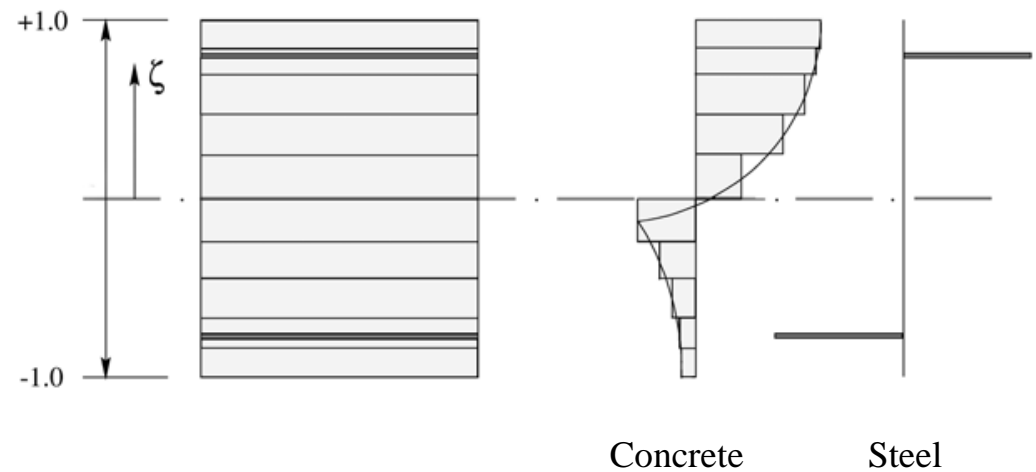

Fig. 1. Layered finite element: (a) degenerate shell element with concrete and steel layers, (b) stresses in concrete and steel layers. 
(a)

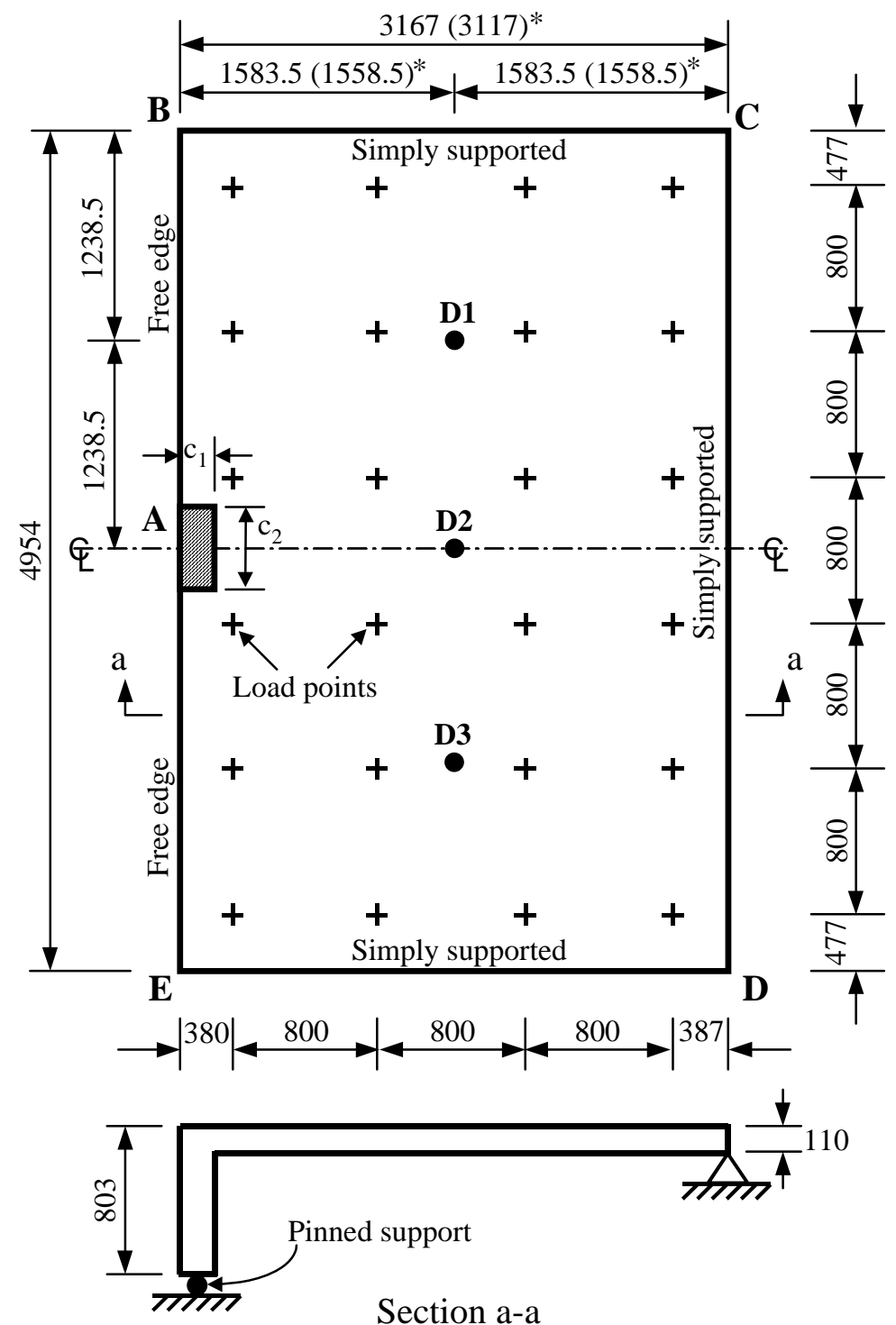

(Note: All dimensions are in $\mathrm{mm}$; * for Slabs 4 to 7 ) 
(b)

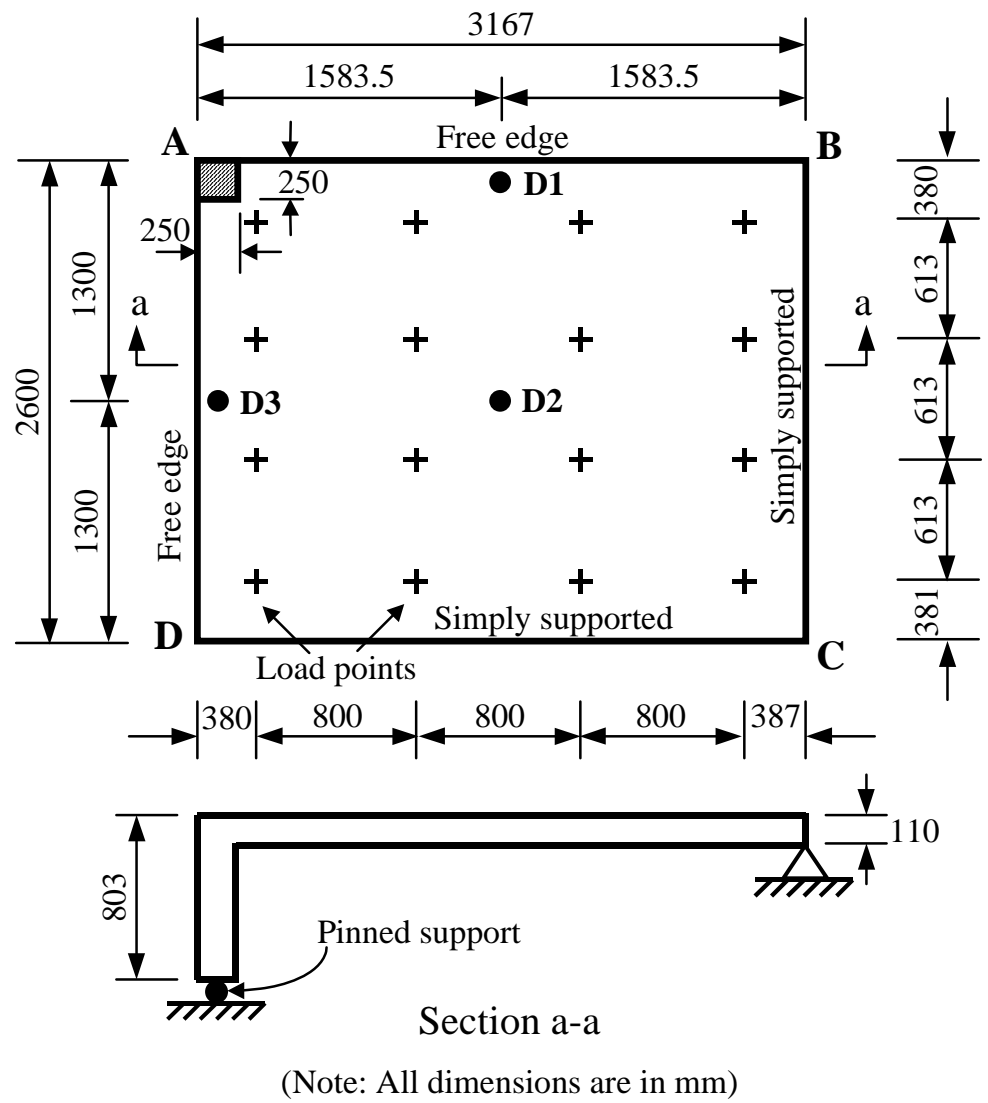

Fig. 2. Layout of test slabs: (a) Slabs 1 to 7, (b) Slabs 8 and 9. 
(a)

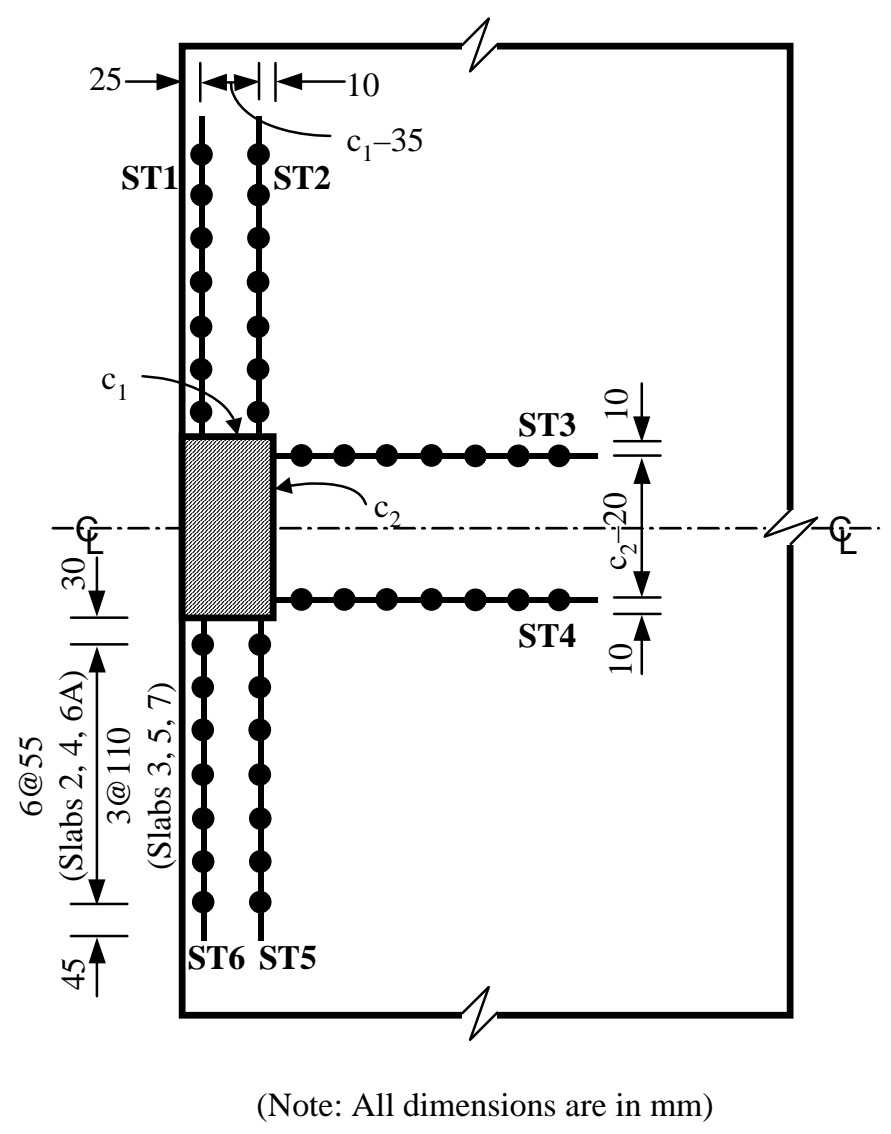


(b)

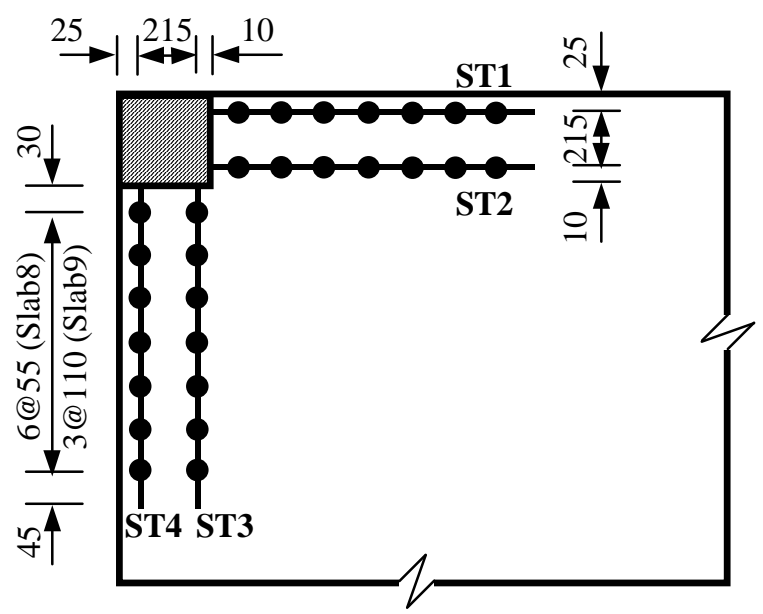

(Note: All dimensions are in mm)

Fig. 3. Arrangement of stud rails in slabs: (a) Slabs 2 to 7, (b) Slabs 8 and 9. 


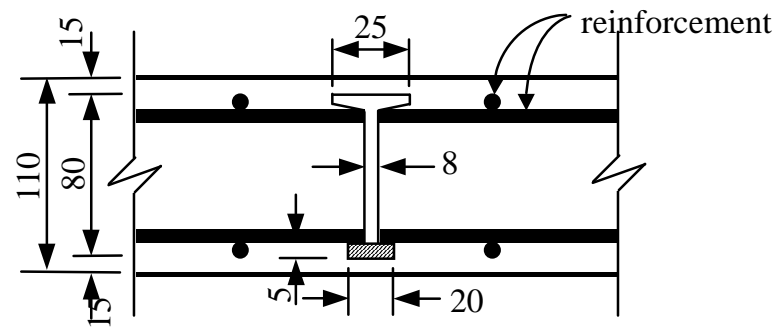

(Note: All dimensions are in mm)

Fig. 4. Position of stud rail in slab. 
(a)

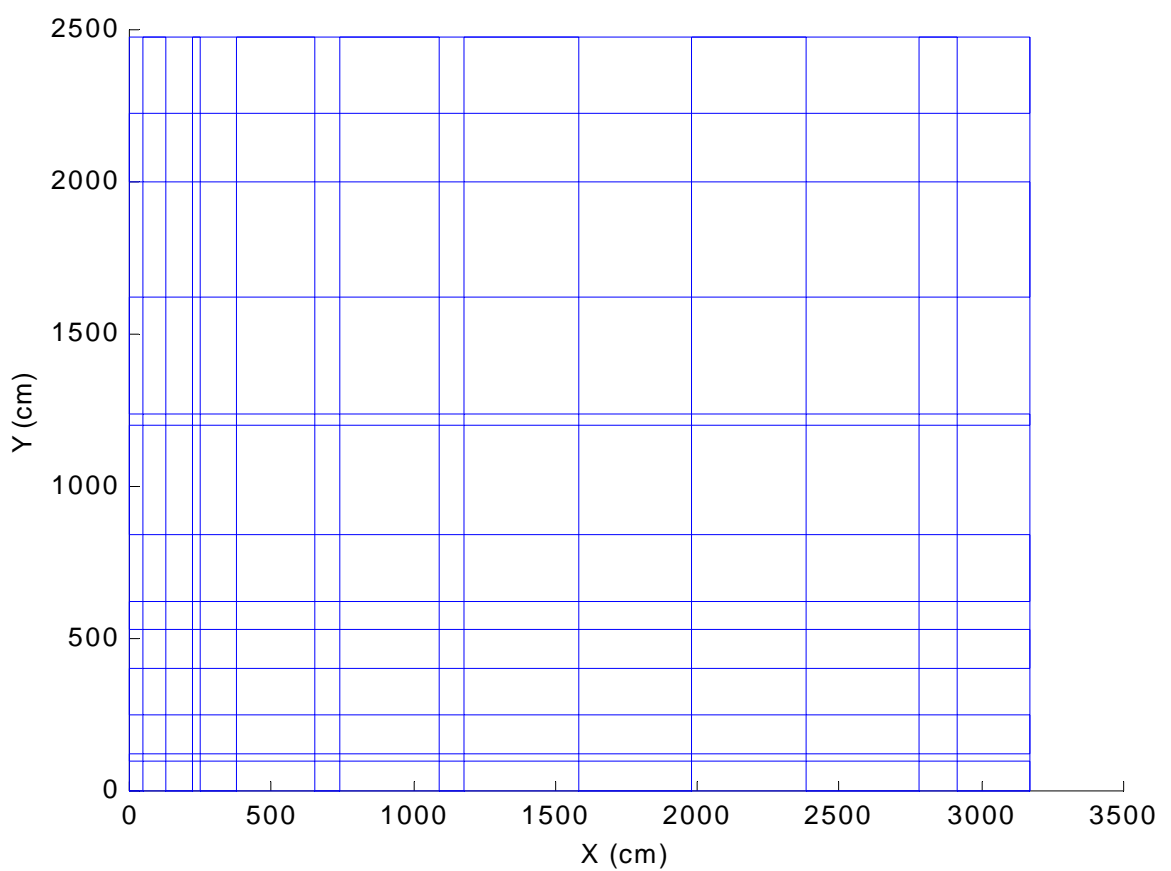


(b)

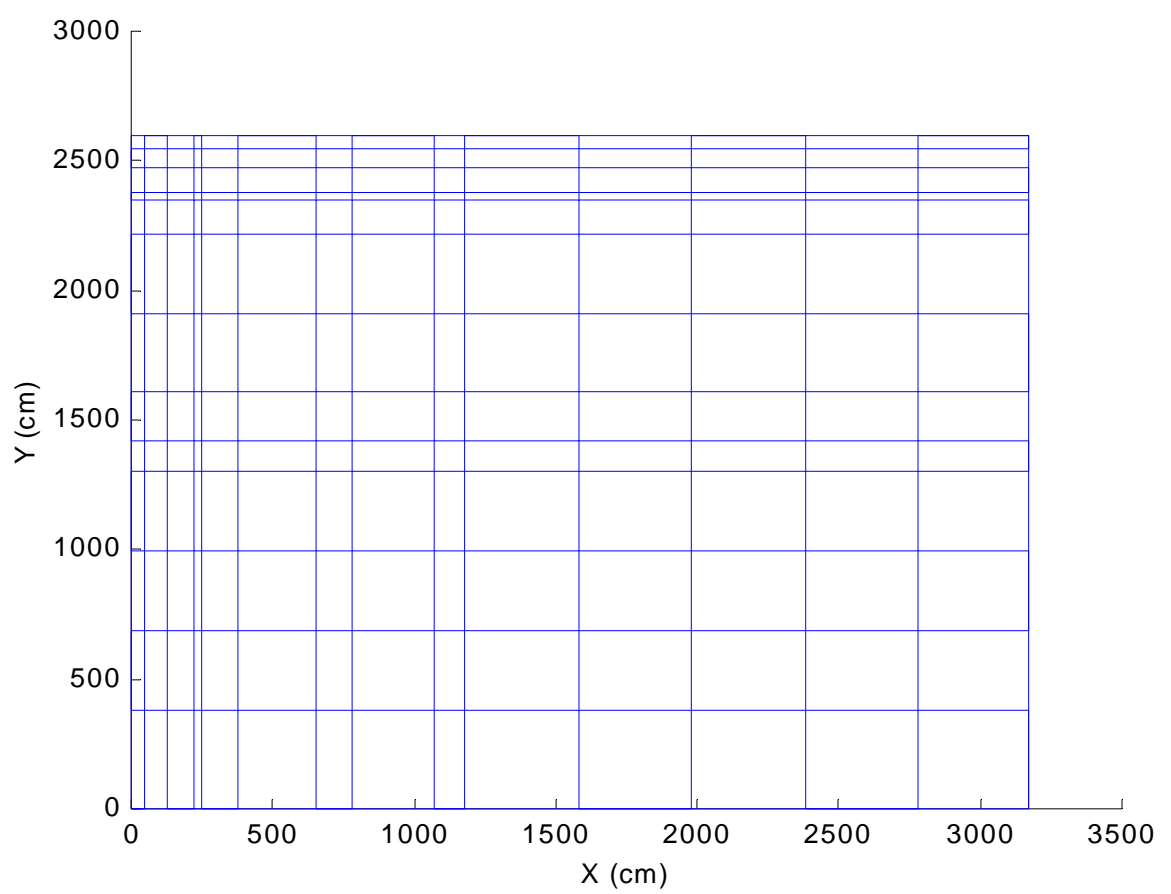

Fig. 5. Finite element mesh: (a) Slabs 2 and 3, (b) Slabs 8 and 9. 
(a)

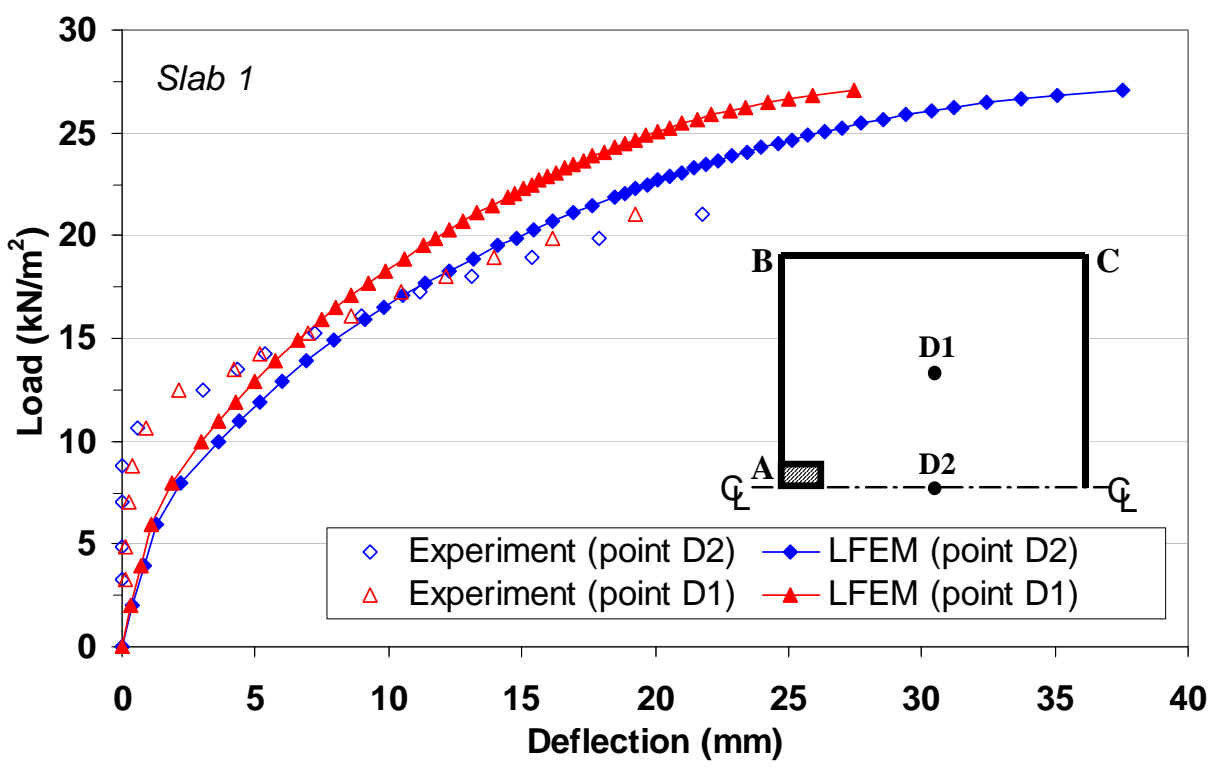


(b)
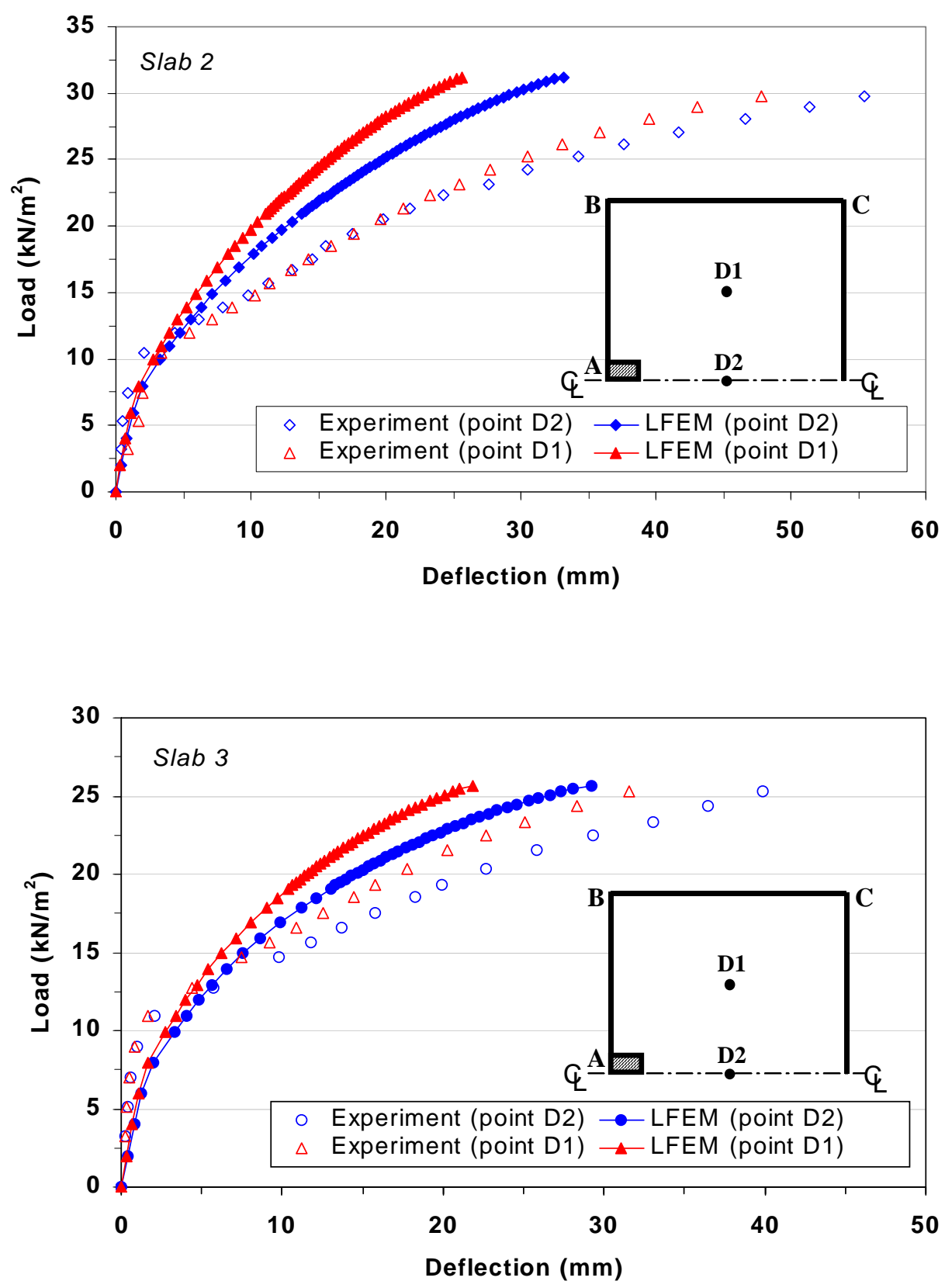
(c)
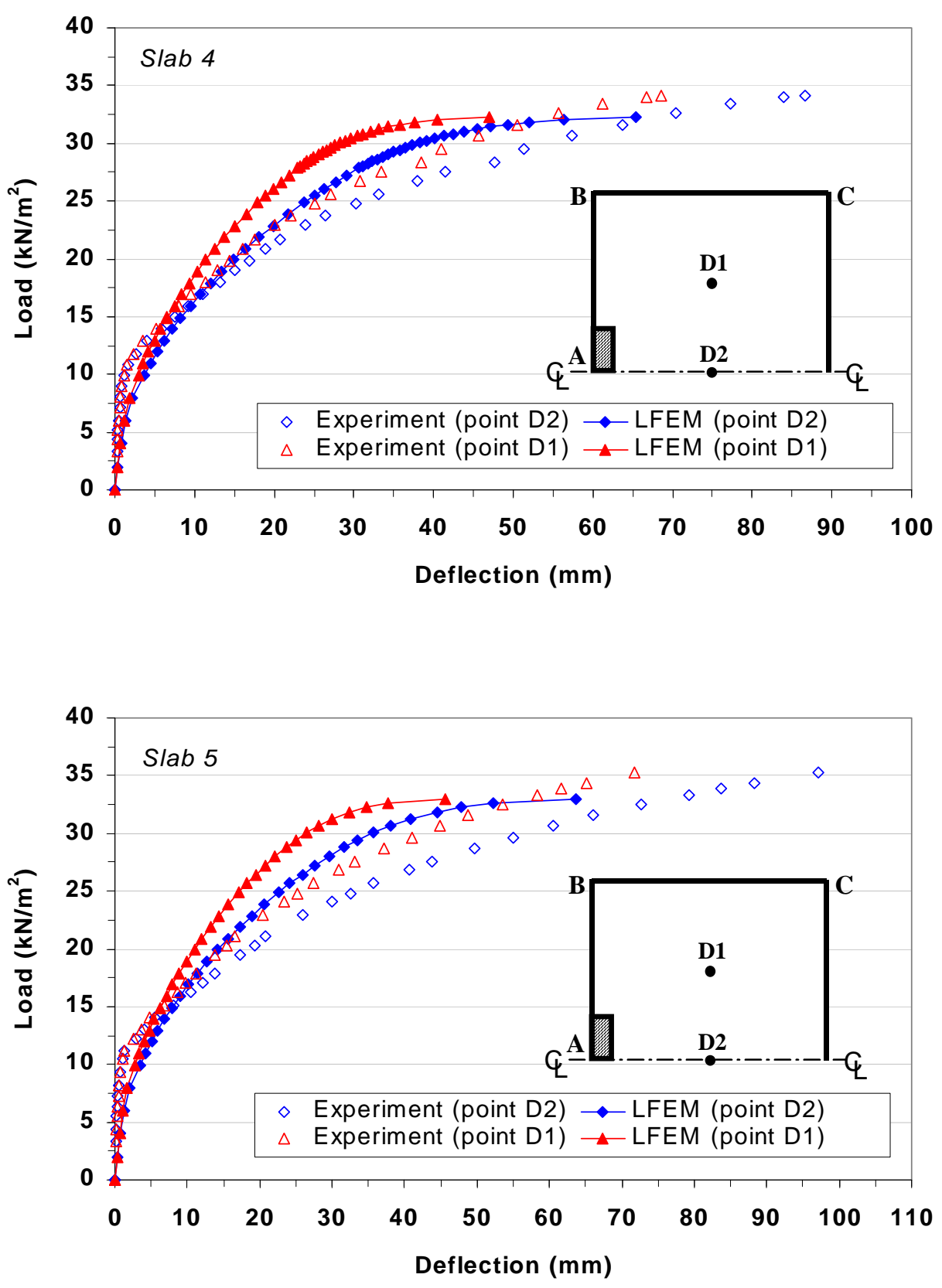

Fig. 6. Load-deflection responses for edge column-slab connections: (a) Slab 1 (control slab), (b) Slab $2\left(c_{1} \times c_{2}=250 \times 250, s / h_{s}=0.5\right)$ and Slab $3\left(c_{1} \times c_{2}=250 \times 250, s / h_{s}=1.0\right)$, (c) Slab 4 $\left(c_{1} \times c_{2}=150 \times 600, s / h_{s}=0.5\right)$ and Slab $5\left(c_{1} \times c_{2}=150 \times 600, s / h_{s}=1.0\right)$. 
(a)

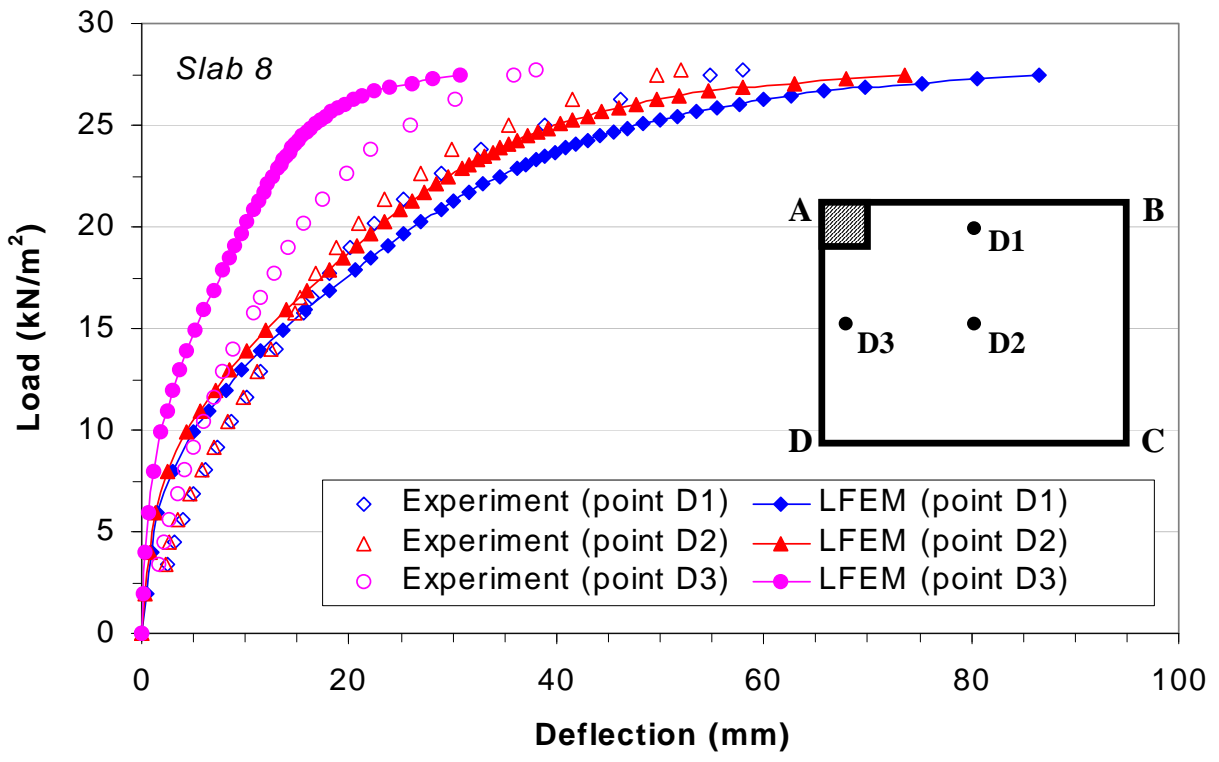


(b)

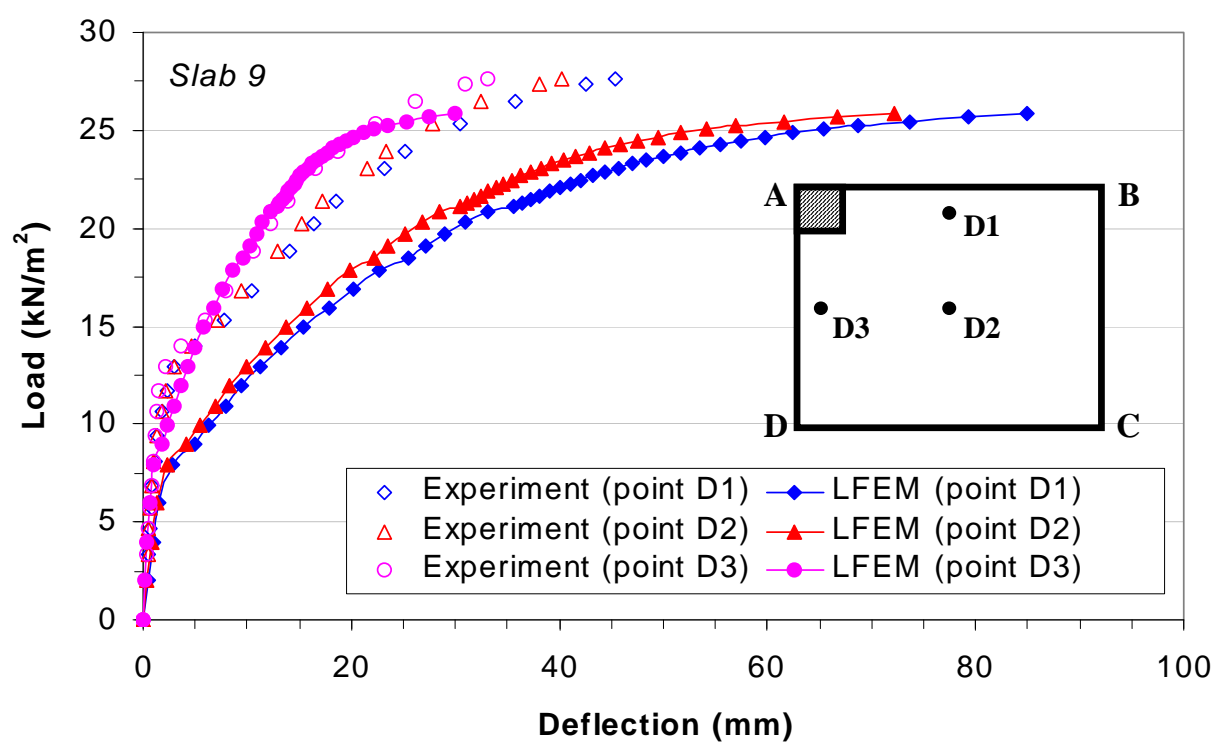

Fig. 7. Load-deflection responses for corner column-slab connections: (a) Slab 8 $\left(c_{1} \times c_{2}=250 \times 250, s / h_{s}=0.5\right)$, (b) Slab $9\left(c_{1} \times c_{2}=250 \times 250, s / h_{s}=1.0\right)$. 
(a)

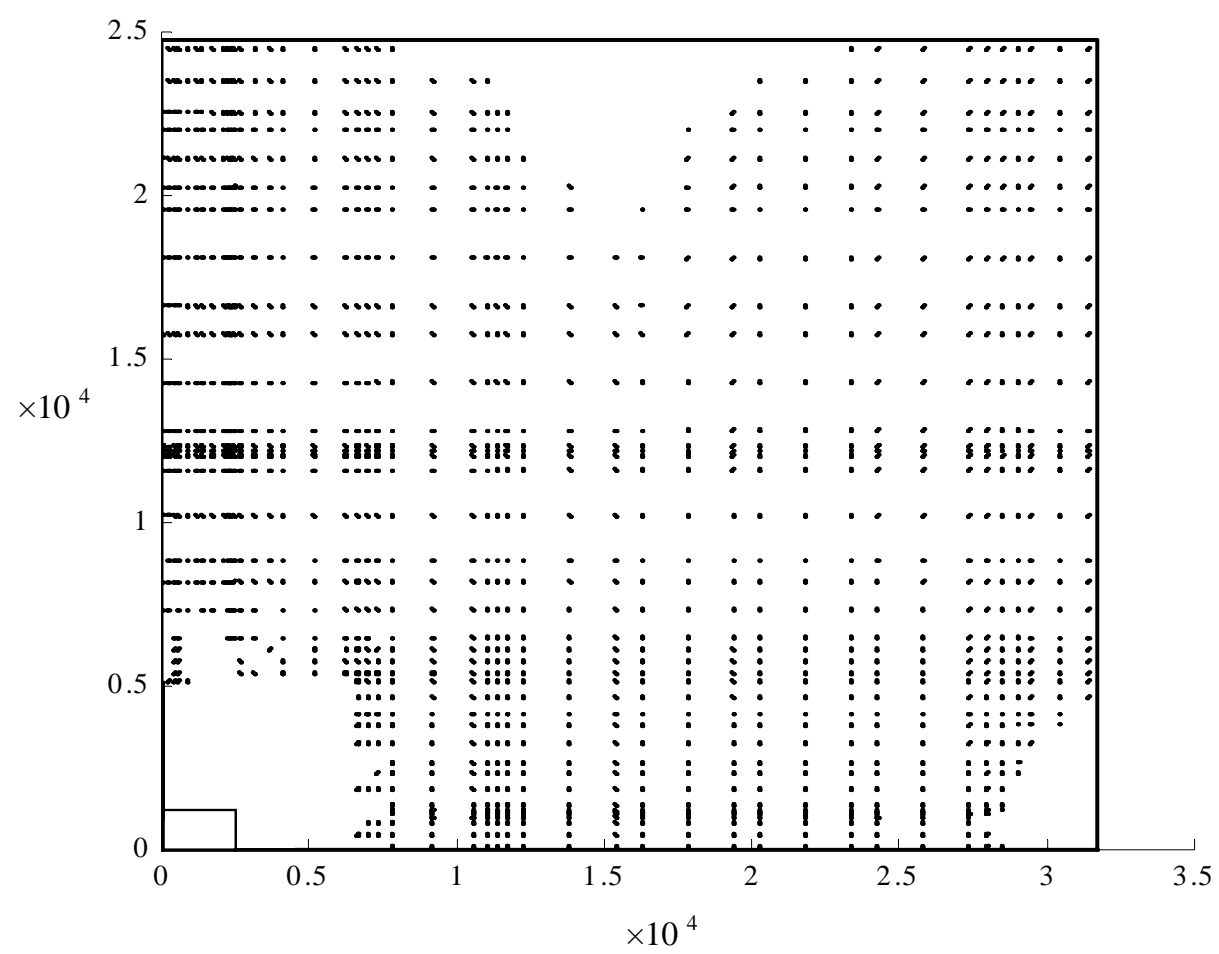


(b)

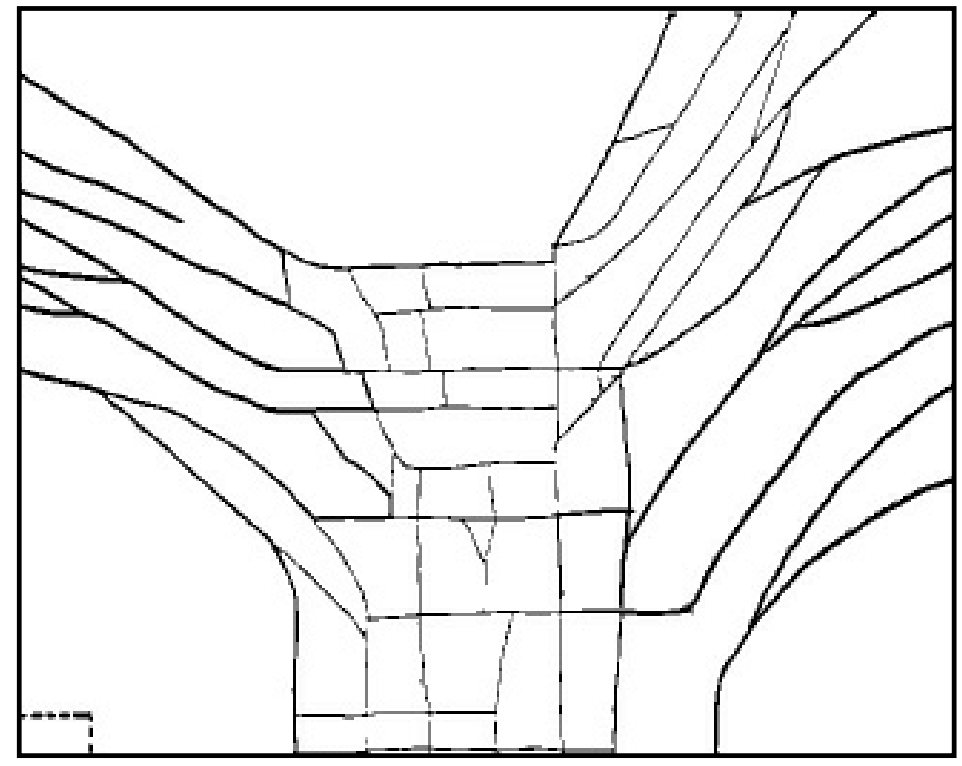


(c)

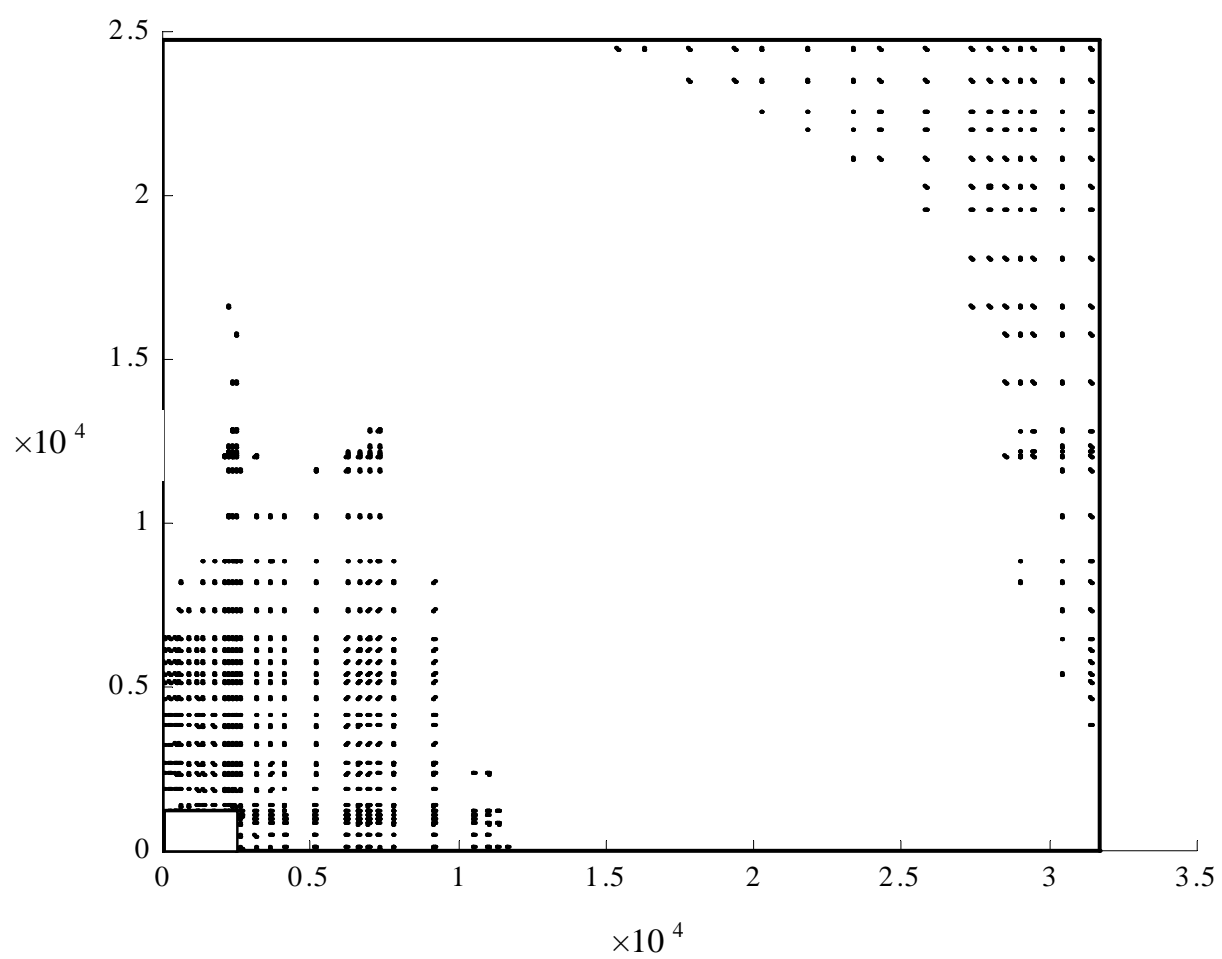


(d)

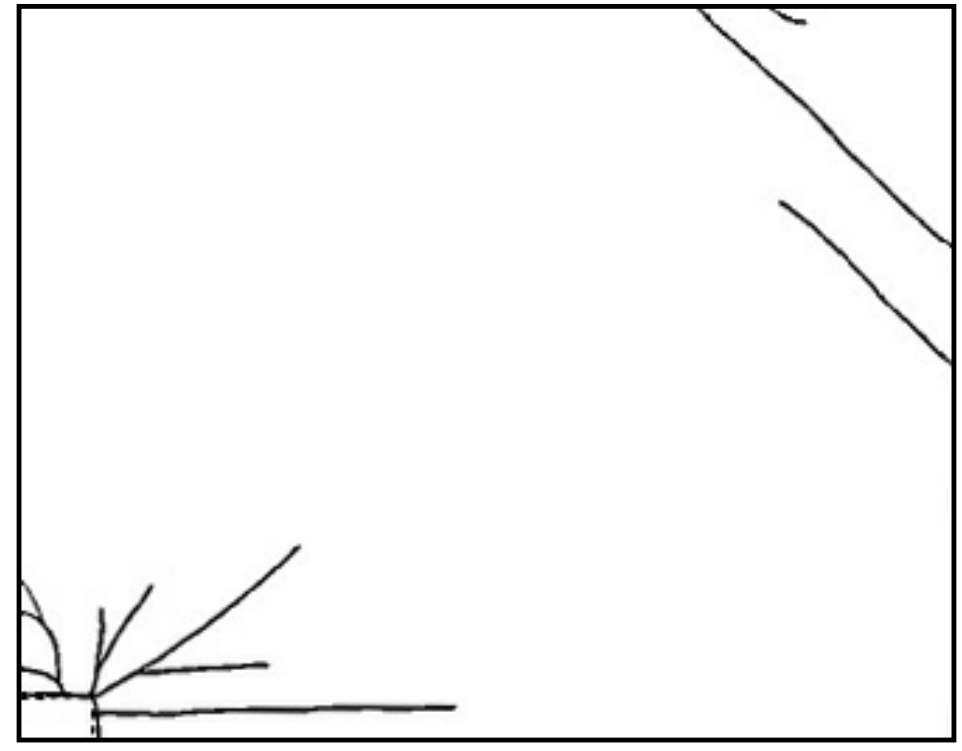

Fig. 8. Comparison of crack patterns for Slab 3 (symmetrical half): (a) predicted pattern for bottom layer, (b) observed pattern of bottom surface, (c) predicted pattern for top layer, (d) observed pattern of top surface. 
(a)

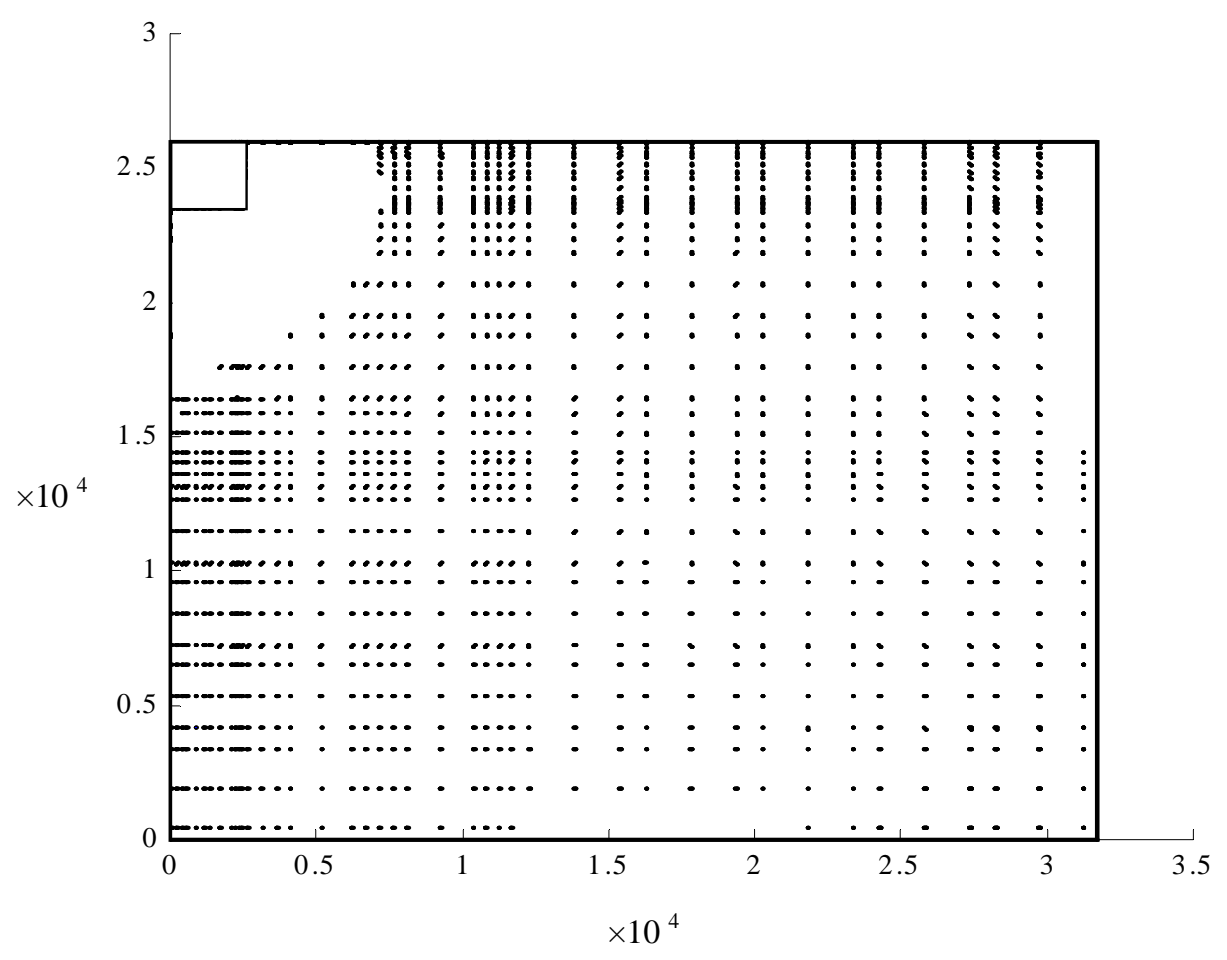


(b)

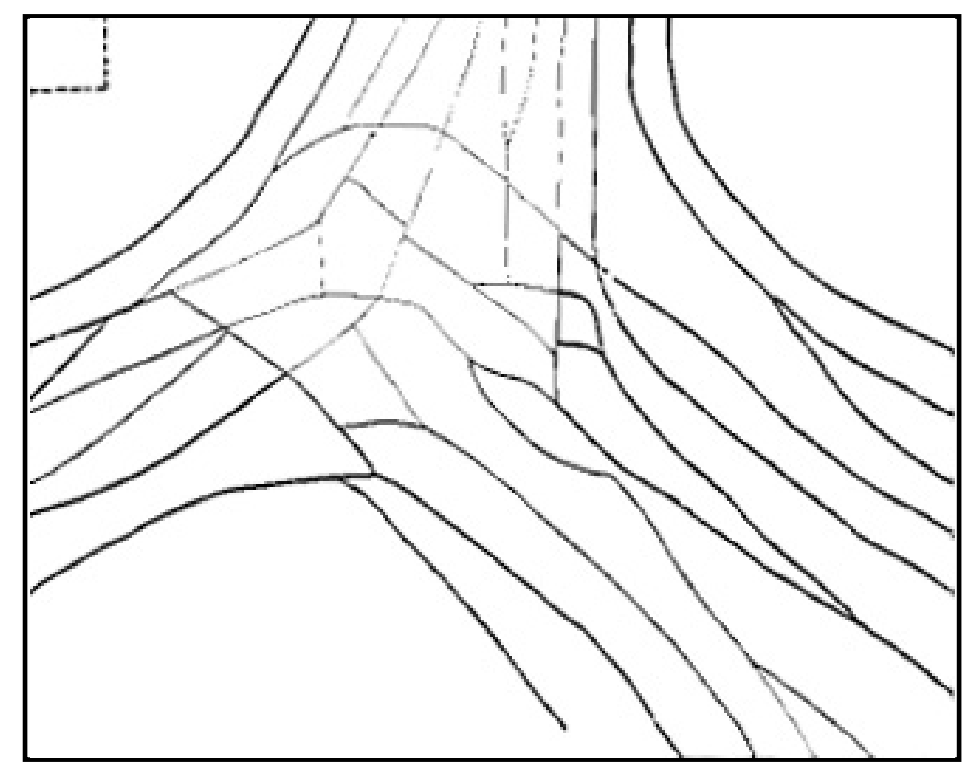


(c)

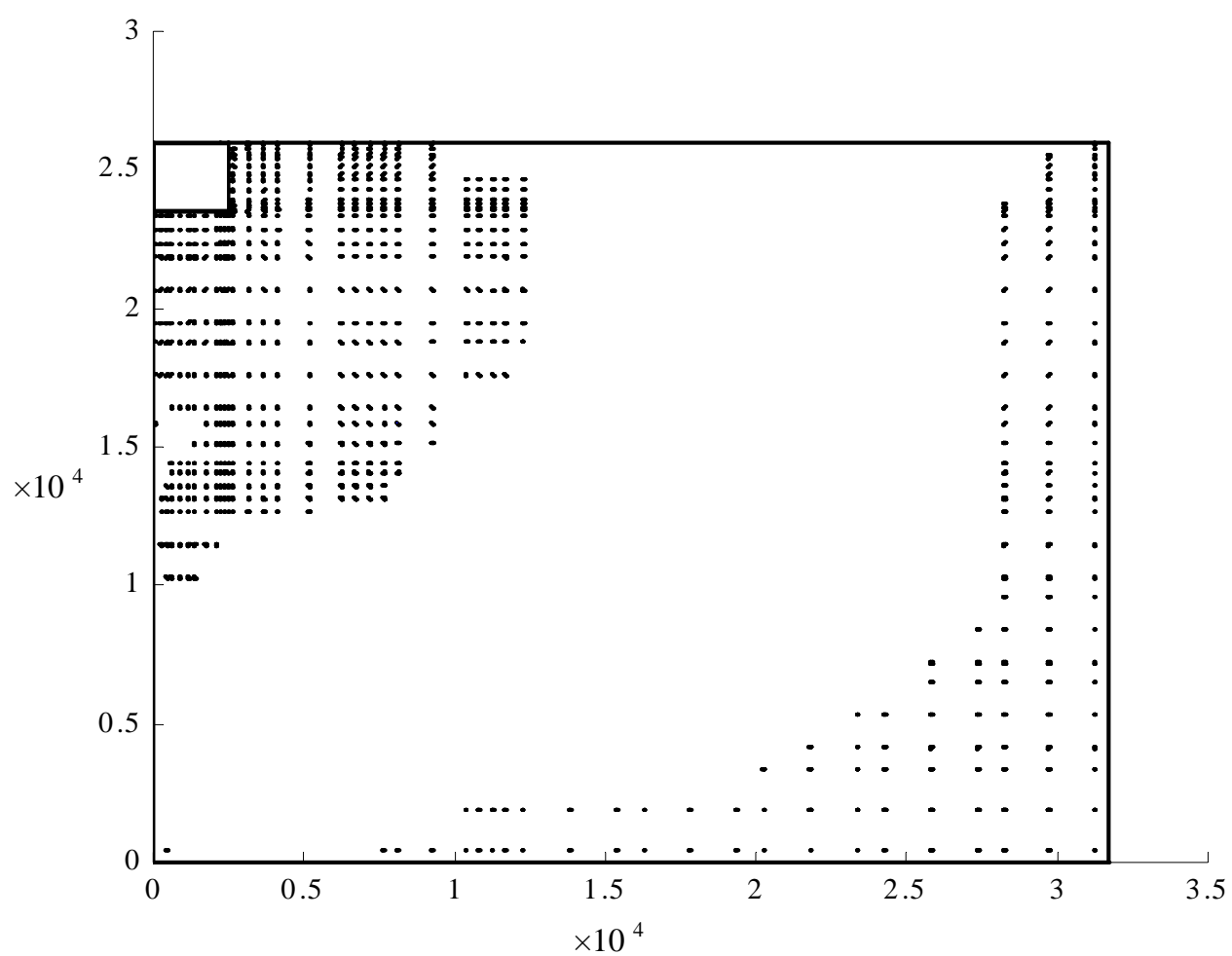


(d)

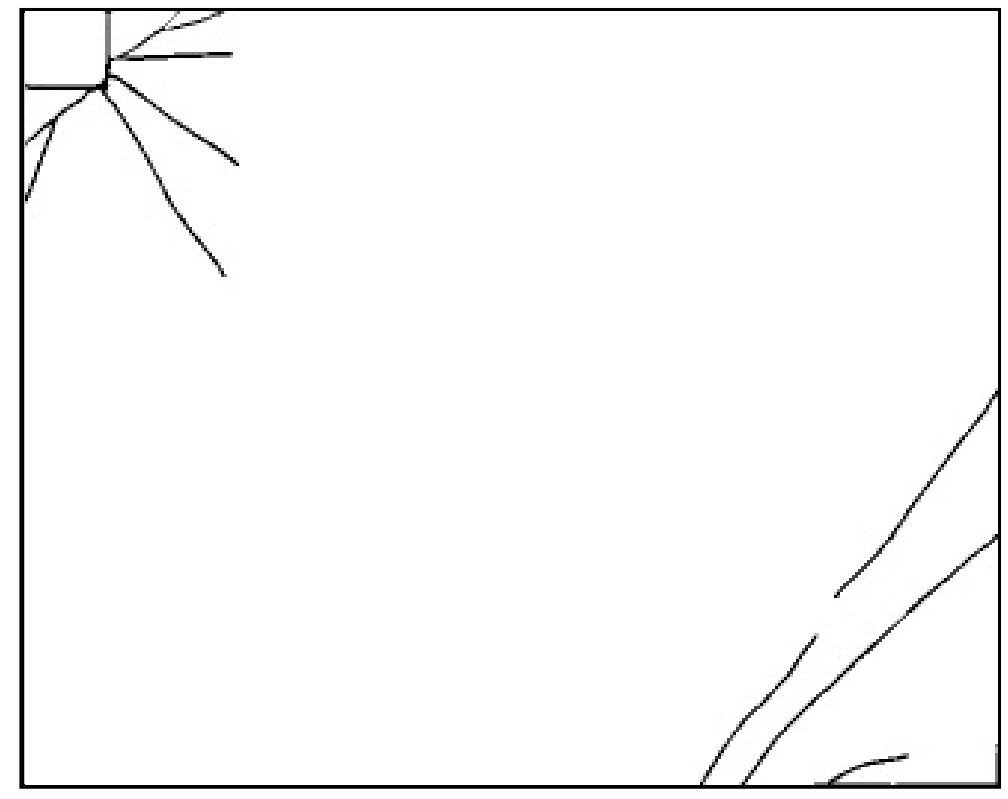

Fig. 9. Comparison of crack patterns for Slab 8: (a) predicted pattern for bottom layer, (b) observed pattern of bottom surface, (c) predicted pattern for top layer, (d) observed pattern of top surface. 